\title{
GLOBALIZED ISRAEL: \\ HIGH TECH PROWESS AND BUTTRESSING FDI
}

\author{
Assaf Razin \\ Working Paper 23223 \\ http://www.nber.org/papers/w23223 \\ NATIONAL BUREAU OF ECONOMIC RESEARCH \\ 1050 Massachusetts Avenue \\ Cambridge, MA 02138 \\ March 2017
}

The views expressed herein are those of the author and do not necessarily reflect the views of the National Bureau of Economic Research.

NBER working papers are circulated for discussion and comment purposes. They have not been peer-reviewed or been subject to the review by the NBER Board of Directors that accompanies official NBER publications.

(C) 2017 by Assaf Razin. All rights reserved. Short sections of text, not to exceed two paragraphs, may be quoted without explicit permission provided that full credit, including $\odot$ notice, is given to the source. 
Globalized Israel: High Tech Prowess and Buttressing FDI

Assaf Razin

NBER Working Paper No. 23223

March 2017

JEL No. F21,F3

\section{ABSTRACT}

The paper reviews the crucial role which globalization forces played in Israel's transformation from low tech to high tech economy. Special emphasis is placed on foreign direct investment as a driver for the high-tech transformation.

Assaf Razin

Eitan Berglas School of Economics

Tel Aviv University

Tel Aviv 69978

ISRAEL

and Cornell University and CEPR

and also NBER

ar256@ cornell.edu 


\title{
Globalized Israel: High Tech Prowess and Buttressing FDI
}

by

\section{Assaf Razin}

\begin{abstract}
The paper reviews the crucial role which globalization forces played Israel's transformation from low tech to high tech economy. Special emphasis is placed on foreign direct investment as a driver for the high-tech transformation.
\end{abstract}

Israel has had a remarkable development, emerging from a low-income developing economy in the 1970 s, to a medium to high income advanced economy in the 2000 s, while increasingly integrated into the world economy in trade, supply chains, and through financial links. The global information-technology surge was the unprecedented growth of Israel's high-tech sector. Innovation requires scale, and scale require trade. An isolated small economy cannot be a center of innovation. The incentives of entrepreneurs to invest effort and resources in generating valuable services are related to the ability to use the resulting knowledge repeatedly, on a large scale, over time. Foreign direct investment provides critical incentives to be able to use scale economies, to leap from the precarious innovation stage at the confined of a small economy to the execution stage, by utilizing the world markets. The globalization of an economy is crucial for its nascent high-tech industry to develop, and flourish.

The paper is organized as follows. Section 1 surveys the crucial role of foreign direct investment for Israel's transformation from low tech to high tech economy. Section 2 addresses labor 
productivity of Israel in comparison to other OECD countries. Section 3 analyzes the effect of ICT technological surge on Israel's high-tech sector. Section 4 elaborates on R\&D international spillovers. Section 5 looks at trends and cycles of the high tech sector, and the economy productivity at large. Section 6 concludes that concerning innovation and technological advance globalization matters.

\section{Foreign Direct Investment}

Foreign direct investment (FDI) has been crucial for the emergence of Israel high tech sector into occupying an elite position in the world economy. Recall that, FDI refers to investments in companies and production outside the realm of the stock market. Whenever a foreign company buys an Israeli start-up, it is counted as FDI. Israel pulled in the fourth highest level of foreign direct investment in relation to the size of its economy in the 2010s. Israel brought in about 4 percent of GDP in FDI. The OECD average was just 1.4 percent. It fell however short of the Ireland at 16.1 percent and Chile at 7.4 percent. For Israel, the OECD accounted for the lion's share of FDI inflows, more than a quarter, of late. The lion's shares came from the United States and the EU. Recently, China became an important source for FDI inflows.

Israel's inward FDI flows accelerated in the 1990s and the 2000s (see Figure 1). Israel's venture capital development (data covers only the 2000s) exhibits a remarkable increase as a proportion of total inward FDI, demonstrating the sharp increase in funding to high-tech startups.

Generally, a multinational firm that chooses to keep the production of an intermediate input within its boundaries can produce it at home or in a foreign country. When it keeps it at home, it engages in standard vertical integration. When it makes it abroad, it engages in foreign direct investment (FDI) and intrafirm trade. High tech start up firm typically attempts to produce a product with two 
distinct characteristics. First, the success of the research and development is highly uncertain, needing venture capital financing because of the high risk. Second, the product is of ultimately multiple uses. That is, it is an input into increasing returns to scale technology; hence attractive to multinational firms. A multinational firm that chooses to keep the production of an intermediate input within its boundaries can produce it at home or in a foreign country. When it keeps it at home, it engages in standard vertical integration. When it makes it abroad, it engages in foreign direct investment (FDI) and intrafirm trade. Deep- pocket international investment enterprises (such as CalPERS' pension fund) tend typically to allocate a small fraction of their investment portfolio to foreign high-tech startups in the form of venture capital. ${ }^{1}$ The high tech firm receiving the funds at the start up stage will have diminished transaction costs at a more mature stage. A multinational

Venture capital picture in Israel goes back to the early 1990s, with capital raising ebbing and flowing and with trends changing. It is highly correlated with inward FDI.

\footnotetext{
${ }^{1}$ For a theory of foreign investor liquidity, venture capital investment and portfolio investment, see Appendix A.
} 
Figure 1: Israeli High-Tech Venture Capital Fund Raising (right axis, Million, current US dollars) and Inward Foreign Direct Investments (left axis, Million, current US dollars)

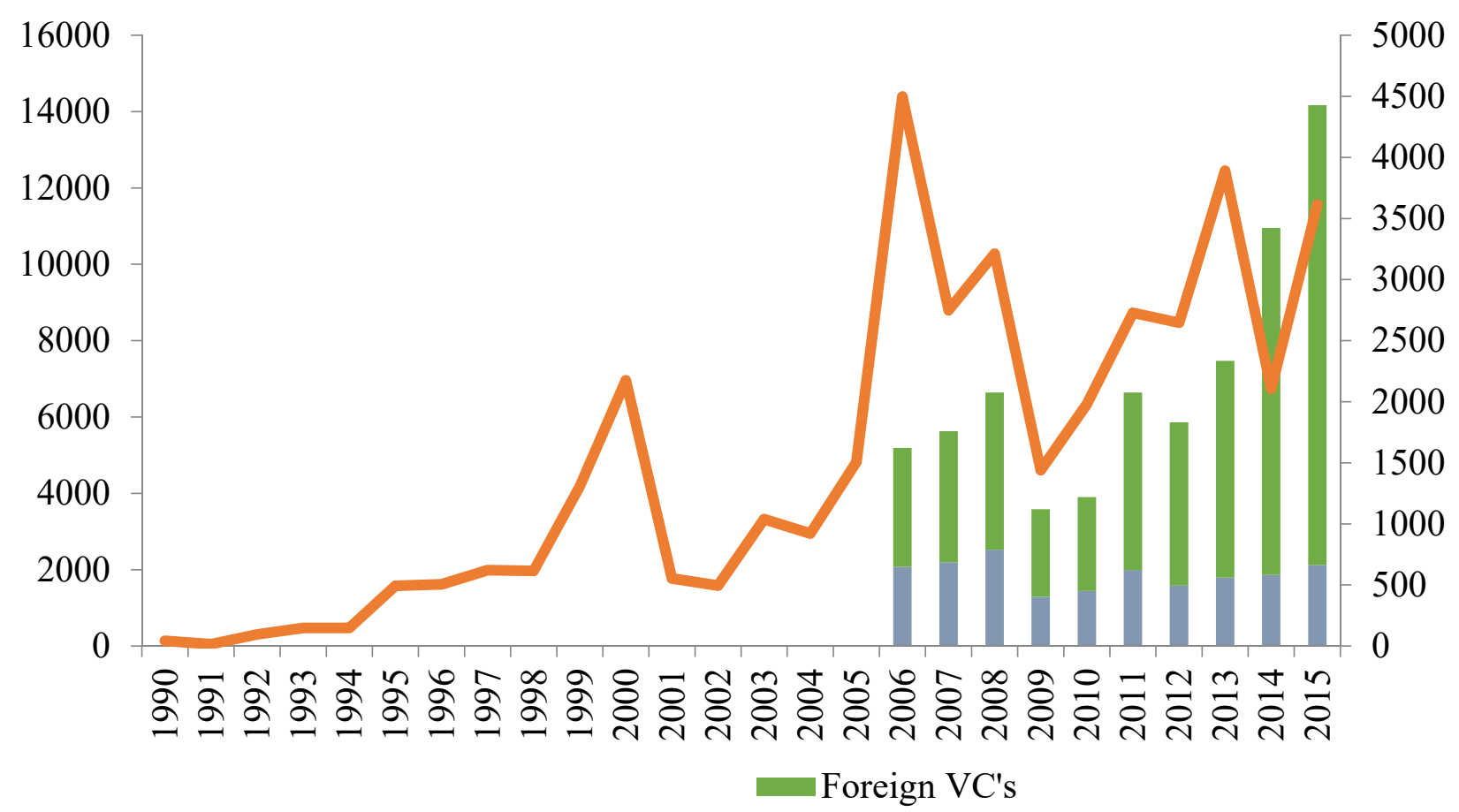

Source: IVC Research Center.

\section{Productivity}

The dot-com bubble was a brief period of surging equity prices in the internet sector and related businesses 1997-2000. Firms discovered that they could increase share prices merely by adding the prefix e (e-Bay) or suffix com (Amazon.com) to their corporate names. Purchasers of dot-com equities and derivatively hard assets gulled themselves into believing that normal standards of valuation could be set aside because dot-com ventures had unbounded profit horizons. The mania had a direct impact on all countries with significant high-tech sectors, including Israel. The dotcom bubble not only the present discounted value of their capital stocks, it triggered large volumes of foreign direct investment (FDI) to other economies, including the emerging high-tech sector in 
Israel; which had beneficial effect on national income both during the bubble and after it burst. This started a steady rise in inward FDI into Israel.

The relatively high $R \& D$ spending has not fully manifested itself in productivity. However, as Figure 2 shows, Israel labor productivity picked up moderately in the 2000s.

Figure 2: 2000-2015 GDP per hour work (constant 2010 prices)

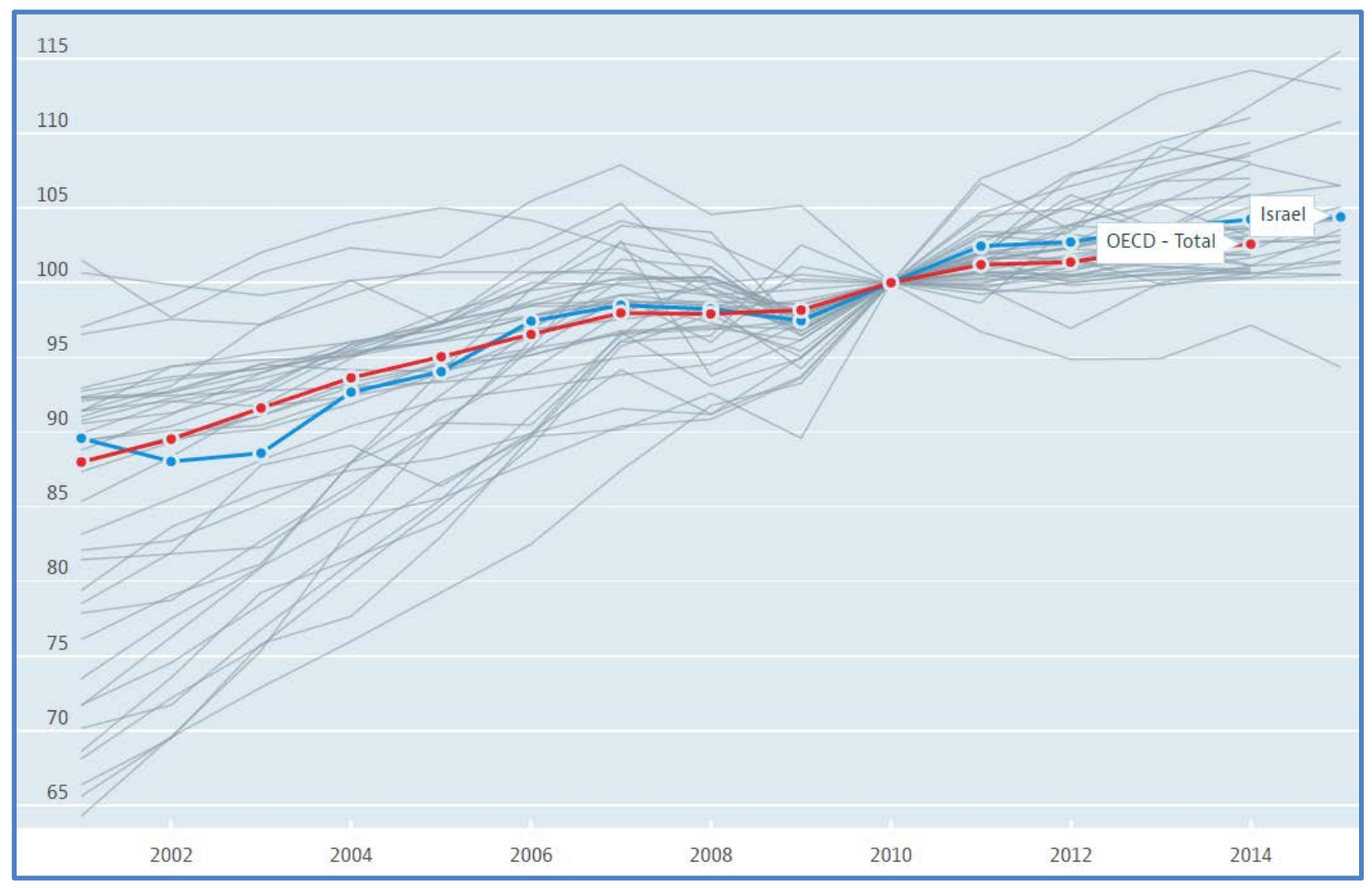

\section{Source: OECD Library.}

Israel recently pulled in the fourth highest level of foreign direct investment in relation to the size of its economy, (OECD library); figures for in 2013. Foreign direct investment refers to investments in companies and production outside the realm of the stock market. Whenever a foreign company buys an Israeli start-up, it is counted as FDI. Israel brought in about 4 percent of 
GDP in FDI. The OECD average was just $1.4 \% .{ }^{2}$ The United States was the source of roughly $30 \%$ of global FDI outflows, followed by Japan, China and Russia. For Israel, the OECD accounted for the lion's share of FDI inflows, primarily the US and the EU, but China's share rises fast. See a brief on FDI literature in Appendix 6A.

3. ICT technological surge and Israel's high-tech sector

We start with potential long-term effects of the global surge in ICT innovations, epi-centered in the US, on factor productivity in small advanced country. The spillover effects of technological innovations have strong implications for the issue that has recently been debated: whether per capita output convergence across developing and developed economies. As observed by Helpman (1999), research-and-development (R\&D) expenditures, which have enormous rates of return, are heavily concentrated within a small number of industrialized countries. If R\&D expenditures do not significantly spill over to developing countries, then R\&D expenditures will tend to widen the cross-country income gaps. Helpman (1999) raises the question of whether the benefits of R\&D expenditures is as skewed as the expenditures themselves, or whether the substantial international spillover effects of R\&D expenditures cause an international distribution of the benefits to be more spread out. Such spillover can mitigate the cross-country income gaps. He bring evidence that for the conclusion that R\&D spillover effects are important and that there exist significant cross-country links driven by foreign trade and FDI. Peri (2005) asserts that knowledge flows within and across countries may have important consequences for both

\footnotetext{
${ }^{2}$ Israel fell short only of the three countries that came ahead of it: tiny Luxembourg, in first place, brought in $39.5 \%$ of its GDP in FDI, followed by low tax Ireland at $16.1 \%$, and Chile at $7.4 \%$.
} 
productivity and innovation. He uses data on 1.5 million patents and 4.5 million citations to estimate knowledge flows at the frontier of technology across 147 subnational regions during $1975-1996$ within the frame of a gravity-like equation. He estimates that only $20 \%$ of average knowledge is learned outside the average region of origin, and only $9 \%$ is learned outside the country of origin. However, knowledge in the computer sector flows substantially farther, as does knowledge generated by technological leaders. In comparison with trade flows, we see that knowledge flows reach much farther. External accessible R\&D gained through these flows has a strong positive effect on innovative activity for a panel of 113 European and North American regions over 22 years.

Coe et al (2009) utilize an expanded data set for the purpose of this study. The new estimates confirm the key results reported in Coe and Helpman (1995) about the impact of domestic and foreign $R \& D$ capital stocks on TFP. In addition, we show that domestic and foreign R\&D capital stocks have measurable impacts on TFP even after controlling for the impact of human capital. Furthermore, we extend the analysis to include institutional variables. Our results suggest that institutional differences are important determinants of TFP and that they affect the degree of R\&D spillovers. Countries where the ease of doing business and the quality of tertiary education systems are relatively high tend to benefit more from their own $R \& D$ efforts, from international $R \& D$ spillovers, and from human capital formation. Strong patent protection is associated with higher levels of total factor productivity, higher returns to domestic R\&D, and larger international R\&D spillovers. Finally, countries whose legal systems are based on French and, to a lesser extent, Scandinavian law benefit less from their own and foreign R\&D capital than countries whose legal origins are based on English or German law. 
Insightfully, de la Potterie and Lichtenberg (2006) investigate econometrically whether foreign direct investment (FDI) transfers technology across borders. (The authors do not study R\&D knowledge transmission mechanism through trade) data indicates that FDI transfers technology, but only in one direction: a country's productivity is increased if it invests in R\&D-intensive foreign countries - particularly in recent years — but not if foreign R\&D-intensive countries invest in it. Other findings are as follows. ${ }^{3}$

Helpman (2003) examines the sources of the rise in total factor productivity (TFP) in Israel in the 1970s and 1980s estimates that slightly more than half the rise in TFP can be attributed to R\&D investment, and the rest to a rise in the level of education.

The ratio of foreign-R\&D benefits conveyed by outward FDI to foreign $R \& D$ benefits conveyed by imports is higher for large countries than it is for small ones. The failure to account for international R\&D spillovers leads to upwardly biased estimates of the output elasticity of the domestic R\&D capital stock; and that are much larger transfers of technology from the United States to Japan than there are from Japan to the United States. ${ }^{4}$

\footnotetext{
${ }^{3}$ For a brief on the FDI literature see Appendix B.

${ }^{4}$ Bransfetter (2006) introduces a framework for measuring international knowledge spillovers at the firm level. He uses this framework to directly test the hypothesis that FDI is a channel of knowledge spillovers for Japanese multinationals undertaking direct investments in the United States. Using an original firm-level panel data set on Japanese firms' FDI and innovative activity, he finds evidence that FDI increases the flow of knowledge spillovers both from and to the investing Japanese firms.
} 
Figure 3: Gross domestic spending on R\&D, Total, \% of GDP, 1981-2014: Israel and OECD average

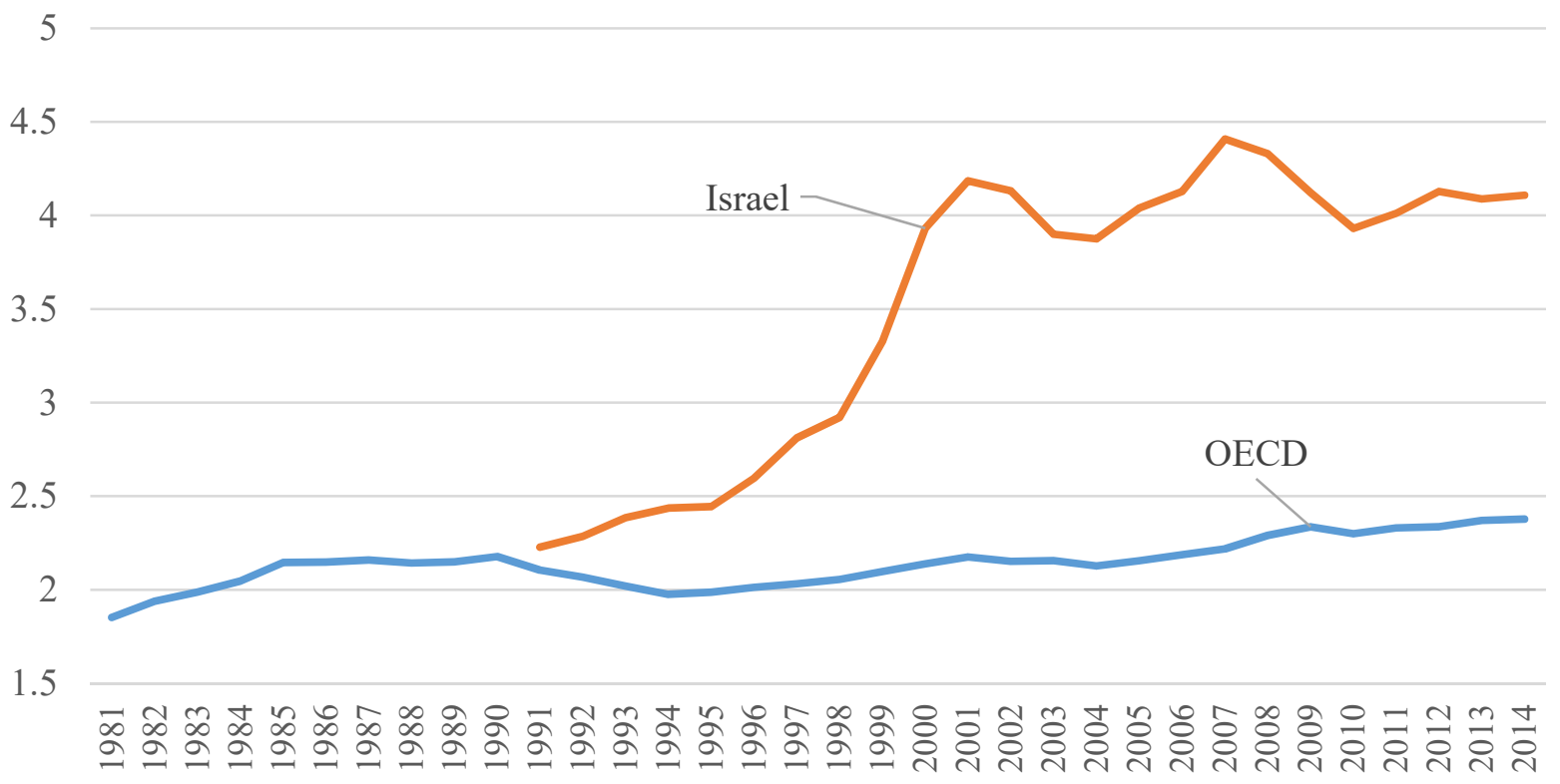

Source: OECD Data.

Israel R\&D spending received a boost after the ICT global surge. Figure 6.3 describes the extent to which Israel domestic spending on R\&D rose sharply to a higher plateau following the global ICT surge in the 1990s. ${ }^{5}$ Israel moved up in OECD ranking. Israel's international ranking in domestic spending on R\&D is truly exeptional.

\section{Spillovers}

We now turn to the transmission mechanism, via the global capital markets, through which the technology surge spreads internationally.

\footnotetext{
${ }^{5}$ Another factor which explain the Israel-OECD gap is the expansion of OECD membership, with some of the new member countries (e.g. Mexico) having low R\&D spending.
} 
International trade, R\&D spillovers and TFP interact with each other in many different ways. Trade increases market size, reduces the duplication of $R \& D$, increases knowledge spillovers, and increases specialization. All of which will increase R\&D and hence TFP. On the other hand, trade increases competition and causes factor prices to change, which leads to a decline in TFP. In addition, trade does not necessarily imply an international convergence of income levels. If the $R \& D$ spillovers are international in scope, there will be convergence; however, if they are national in scope, there will be a divergence. (See Helpman (2004)).

Capital flows of all types have increased over the past few decades, and most recently, some of the biggest increases have occurred in foreign direct investment. This is especially true of rich countries, but is also increasingly true of developing nations too. Obstfeld and Taylor (2002) make an historical point: "A century ago, world income and productivity levels were far less divergent than they are today, so it is all the more remarkable that so much capital was directed to countries at or below the 20 percent and 40 percent income levels (relative to the United States). Today, a much larger fraction of the world's output and population is located in such low-productivity regions, but a smaller share of global foreign investment reaches them."

Foreign direct investment (FDI) occurs when an investor based in one country (the home country) acquires an asset in another country (the host country) with an intent to manage that asset. The management dimension is what distinguishes FDI from portfolio investment in foreign stocks, bonds and other financial Instruments. Inward FDI in the high tech sector is driven by human capital easy to do business in the host country. However, FDI flows, namely the acquisition of the high-tech industry equity assets, provide strong incentive to innovate. Thus, FDI flows help to expand the high tech sector activities. In other words, FDI flows are both driven by fundamentals, which drive the high tech industry, and re-enforcing its expansion. Israel's high-tech development 
in the last two and a half decades is a fascinating event study, flashing out the FDI-Productivity interactions. ${ }^{6}$ Capital flows of all types have increased over the past few decades, and most recently, some of the biggest increases have occurred in foreign direct investment. This is especially true of rich countries, but is also increasingly true of developing nations too.

Turning to the short-term aspects of FDI, we consider how they are related to the global stockmarket cycle. Capital flows in the form of FDI are important because it is believed that FDI has special benefits over other forms of capital flows. First, these flows are thought to be more stable, and do not leave the host country exposed to financial crises. Second, FDI if often supposed to be associated with technology transfer, which may have spillover benefits for the host country. Third, FDI is often attributed a special role in disciplining host country governments: the threat of moving business offshore limits the ability of host countries to extract taxes and introduce inefficient regulations. Offsetting this, FDI is also often associated with special domestic costs in cases where foreign ownership has caused domestic political unrest in the host country (this is often especially true in natural resource industries). ${ }^{7}$

\footnotetext{
${ }^{6}$ Not all countries follow the $10 \%$ mark for the definition of FDI. Most countries do indeed report long-term intrafirm loans, but not all countries report short-term loans. Most countries report reinvestment of retained earning only with a considerable lag. One implication of these measurement problems is that FDI inflows do not contemporaneously match FDI outflows. UN (2005) annual report on world investment documents how countries are becoming more receptive to FDI. In the years 1991-2004 vast majority of changes in laws and regulations pertaining to investment were more favorable to FDI. An exception is developing countries which introduced some laws and regulations intended to protect some natural resources (especially in the energy field) against "foreign intruders". The report also indicates that countries are cooperating with each other in designing pro-FDI bilateral policies: "The number of bilateral investment treaties (BITs) and double taxation treaties (DTTs) reached 2,392 and 2,559 respectively, in 2004, with developing countries concluding more such treaties with other developing countries." Razin and Sadka (2007) provide a comprehensive survey of theory and empirical applications of FDI.

${ }^{7}$ See also Feenstra (1999).
} 
Being equity investments, FDI flows are driven among other factors by credit availability and stock market performance. A central problem in the credit market is that lenders are reluctant to make loans because they cannot easily determine whether a prospective borrower has resources to repay the loan. If the loan is made, the lender is concerned about whether the borrower will engage in risky behavior that could lower the probability that the loan will be repaid. Collateral reduces this information asymmetry problem because high-quality collateral (that is, assets that are easily valued and easy to take control of) significantly decreases the losses to the lender if the borrower defaults on the loan. High-quality collateral also reduces the moral hazard problem because the borrower is reluctant to engage in excessively risky behavior since now he or she has something to lose. Creditor protection enhances the ability of the lender to take control of the collateral in case of default and thereby alleviate credit constraints. Thus, creditor rights regulation helps to mitigate the problems of information asymmetry and moral hazard between creditors and borrowers. Hale et al (2014) develop a model predicting two channels through which creditor protection enhances the performance of stock prices: the probability of a liquidity crisis leading to a binding investment-finance constraint falls with a strong protection of creditors; the stock prices under the investment-constrained regime increase with better protection of creditors. They find strong empirical support for both predictions using data on stock market performance, for 52 countries over the period 1980-2008. In particular, they demonstrate that better creditor protection is correlated across countries with lower average stock market volatility; crises are more frequent in countries with poor creditor protection. Using propensity score matching they demonstrate that during crises stock market returns investment fall by more in countries with poor creditor protection. ${ }^{8}$ Israel has had international high ranking in credit protection. It became also an

\footnotetext{
${ }^{8}$ The reason is that creditor rights protection affects the probability of the crisis. Hale et al (2014) estimate PROBIT regressions of stock market crashes. They construct the propensity score and match crisis observations (treatment
} 
attractive place for foreign direct investment at the time the high tech industry, capitalizing on Israel's human capital, emerged into the world economy.

\section{High Tech Israel: Cycles and Trends}

Israel high tech industry benefitted from a surge in inward FDI. ${ }^{9}$ Figure 4 describes the timepattern of FDI inflows in Israel, compared with the ones in other developed economies.

\section{Figure 4: Foreign direct investment: Inward flows, annual, 1980-2013 (percentage of Gross Domestic Product)}

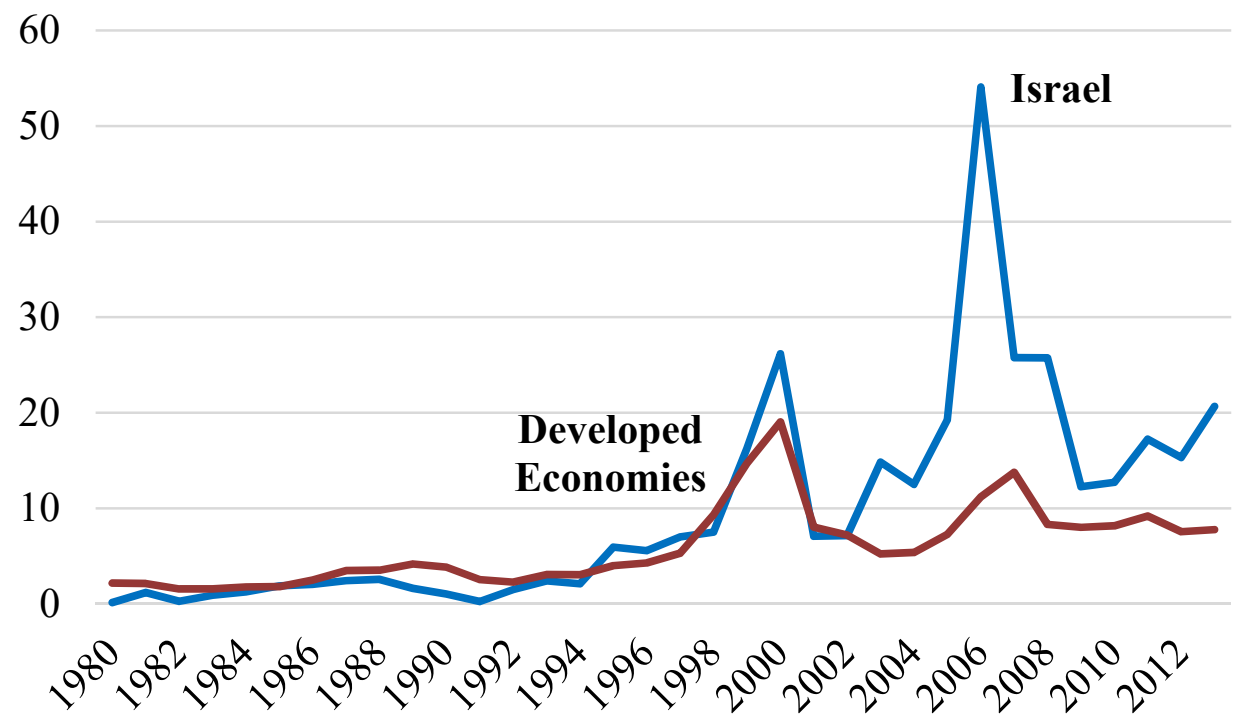

Source: United Nations Conference on Trade and Development database

group) to non-crisis observations (control group), by using Epanechnikov-kernel matching technique. Having done this, they then compute average treatment effect on treated (ATT), using the matched sample, for stock market return and volatility. They find that the stock market average return is only half as high during the crisis; and that in a matched sample the stock return volatility is substantially and significantly higher during crisis,

${ }^{9}$ Globalization in the shape of a drop-off of capital controls typically lead to foreign direct investment in the form of mergers and acquisition (M\&A), but not in the one in the form of greenfield investment. The latter are typically encouraged in the political-economy setups, even under a regime of capital-inflow restrictions, provided that the profits from the investments are allowed to be repatriated. Greenfield FDI surges are primarily driven by high return projects such as high-tech start-ups. 
To interpret Figure 4, FDI flows (in percentage of gross domestic product) as reflecting the intense interactions of the FDI flows with investment in the high tech investment in Israel. Three features are noteworthy:

(1) The sharp rise in inward FDI during the dotcom equity bubble;

(2) The effect of the dotcom early 2000s equity that triggered a temporary fall in inward FDI flows. Inward FDI underwent a sharp rise in the late 1990s. The upturn happened when the nascent high tech industry in Israel emerged on the global stage, and the upside-down- $\mathrm{V}$-shaped fall when the early 2000 s dotcom equity collapse took place; and,

(3) The effect of the boom and bust of the equity markets around the 2008 crisis when Israel high tech industry gained strength in global high tech sectors.

Helpman (2003) observes that over the last decades Israel's economy grew faster than average, but not exceptionally fast. Compared with countries at a similar level of development, Israel is not outstanding. Seven-tenths of the rise in its GDP can be explained by the increase in labor input (measured by hours worked) and investment in machinery, structures, and equipment. Nonetheless, the investment is made possible by the increase in productivity, which in turn was fed by improved levels of schooling, investment in $R \& D$, and knowledge spillovers from other countries. Based on the level of schooling and the stock of R\&D.

Israel's economy is the most tech-dependent in the world, with 13 percent of the country's GDP and 31 percent of all exports originating in the high tech sector; thus, the global high tech slowdown has hit Israel harder than other advanced economies. 
Friedmann (2016) analyze the implications for labor productivity of the three groups of external shocks hit the industry since the early 1990s: Mid 1990s---before the "Birth" of the dotcom bubble:

1. Early 2000s- after the burst of the dotcom bubble;

2. Before and during the early stages of the $\mathbf{2 0 0 8}$ global crisis which triggered the global stock market crash and the sharp decline in world trade.

3. The Great Recession that followed the global crisis.

The Table exhibits the high productivity increase of the private and the ICT sectors around the global ICT surge in the 1990s; the low productivity increase in the early 2000s in the sectors following the burst of the dot.com bubble; and the return to a state of medium-to-high productivity change before the 2008 global stock market crash. 
Table 4: Israel's Labor Productivity (annual percentage changes)

\begin{tabular}{|c|c|c|c|c|}
\cline { 2 - 5 } \multicolumn{1}{c|}{} & $1991-1995$ & $1996-2000$ & $1996-2010$ & $2006-2010$ \\
\hline $\begin{array}{c}\text { Private } \\
\text { Sector: Total }\end{array}$ & $\begin{array}{c}1.5 \\
(1,399)\end{array}$ & $\begin{array}{c}3.5 \\
(1,559)\end{array}$ & 1.5 & $\begin{array}{c}1.2 \\
(2,057)\end{array}$ \\
\hline $\begin{array}{c}\text { Information } \\
\text { Technology } \\
\text { Sector }\end{array}$ & 1.1 & 10.2 & 3.4 & 1.7 \\
\hline $\begin{array}{c}\text { Information } \\
\text { Technology } \\
\text { (excluding } \\
\text { electronics) }\end{array}$ & 3.1 & $(126)$ & $176)$ \\
\hline & $(35)$ & $(38)$ & 6.0 & 3.3 \\
\hline $\begin{array}{c}\text { IT Services } \\
\text { (3) }\end{array}$ & -3.6 & 5.7 & & $(38)$ \\
\hline
\end{tabular}

Source: Friedman (2016).

Note: in parentheses are the number of employees (in thousands).

There is an intriguing positive correlation between high tech industry productivity (shown in Table 4) and FDI flow cycles (shown in Figure 6.1). The clustering of high tech industries and start up primarily in Tel-Aviv, Israel's commercial center and its economic activities is another productivity-enhancing development. In general, productivity-boosting mechanisms arising from the clustering of high-tech and university centers is complimentary to the productivity-enhancing effects of industrial agglomeration. These have attracted great attention in policy circles Empirical evidence suggests that region-level productivity rises 3-8\% when market size is doubled (World Bank 2009).In a recent study, we employ plant-product-level data from Japanese manufacturing to assess the effects of urban agglomeration on product quality (Saito and Matsuura 2016). Their 
findings suggest that state and municipal tax breaks and other public efforts to attract enterprises enhance economic competitiveness by improving product quality along with productivity. Productivity gains used to project traditionally agglomeration benefits underestimate the benefits by ignoring the quality incentives accompanying a productivity shock.

\section{Globalization Matters}

Globalization is currently facing some challenging political tests, more than in the past decades. Brexit may have been the first wave of anti-globalization and rising populism that gushes over the most advanced nations. Globalization and new-technology forces trigger a steady decline in low-tech manufacturing industries, a rise in global financial centers, and increased immigration flows, brought up the 2017 change of guards in the US. Meanwhile, European countries like France, Greece, the Netherland, Spain, Demark and others witness the anti-EU forces gather strength. The EU refugee crisis, The EMU crisis, the political backlash against trade treaties in the US; which threatens the proposed multi-lateral trade agreements such as the Trans-Atlantic Trade and Investment Partnership (US-EU trade deal) and the TransPacific Partnership (US-Asia trade deal), and more. The open-border model, which governed the global economy for more than 70 years, is unravelling. However, the acceleration of finance, technology and telecommunication and supply chains makes the reversal from globalization self-defeating. The remarkable transformation of Israel's economy from low tech to high tech through trade and financial integration in the world economy provides a strong counter example to the anti-globalization logic. 


\section{Appendix A: A model of foreign venture capital investment ${ }^{10}$}

Consider a small economy faced by a continuum $[0,1]$ of foreign investors. Each foreign investor has an opportunity to invest in one investment project, as in B- to-B transactions (FDI). Foreign investment can occur in one of two forms: either as a direct venture capital, the direct investor effectively acts like a manager; or, as a portfolio investment, the investor does not manage the project.

There are three periods: 0,1 , and 2 . In period 0 , each investor decides whether to make a direct investment or a portfolio investment. In period 2, the project matures. The net cash flow from the start-up project is given by

$$
R(K, \varepsilon)=(1+\varepsilon) K-\left(\frac{1}{2}\right) A K^{2}
$$

where $\varepsilon$ is an idiosyncratic random productivity factor, which is independently realized for each project in period 1 , and $K$ is the level of capital input invested in the project in period 1 , after the realization of $\varepsilon$. The parameter $A$ reflects production costs. The productivity shock $\varepsilon$ is distributed between -1 and 1 with mean 0 with the cumulative distribution function, $\Phi(\cdot)$, and the density function is $f(\cdot)=\Phi^{\prime}(\cdot)$. Investors choose the form of investment that maximizes (ex ante) expected payoff.

In period 1, after the realization of the productivity shock, the manager of the project observes $\varepsilon$. Thus, if the investor owns the project as a direct investment, she observes $\varepsilon$, and chooses $K$, so as to maximize the net cash flow: $K^{\mathrm{d}}(\varepsilon)=(1+\varepsilon) / A$.

\footnotetext{
${ }^{10}$ Based on Goldstein and Razin (2006).
} 
Therefore, the ex ante expected net cash flow from a direct investment, if held until maturity, is

$$
E V_{\mathrm{d}}=\frac{E\left[(1+\varepsilon)^{2}\right]}{2 A}
$$

In the case of a portfolio investment, the owner has an arm's-length relationship with the manager, and thus she cannot observe $\varepsilon$. In this case, the owner maximizes the expected return absent any information on the realization of $\varepsilon$; and decisions are based on the ex ante zero mean. Thus, the manager will be instructed to choose $K^{\mathrm{p}}=K^{\mathrm{d}}(0)=(1 / A)$. Then, the ex ante expected payoff from a portfolio investment, if held until maturity, is

$$
E V_{\mathrm{p}}=1 /(2 A)
$$

Comparing (6A.2) with (6A.3), we see that if the project is held until maturity, it yields a higher payoff as a direct investment than as a portfolio investment. This reflects the efficiency that results from a hands-on management style in the case of a direct investment.

There are also costs for FDI investment, however. First, an FDI investor has to incur a fixed cost in order to acquire the expertise to manage the project directly. We denote this cost, which is exogenously given in the model, by $C$. Second, there is an endogenous cost arising from the possibility of liquidity shocks occurring in period 1 . There is a discount when selling a project managed as direct investment due to information asymmetries, as demonstrated below.

In period 1 , before the value of $\varepsilon$ is observed, the owner of the project might get a liquidity shock. With the realization of a liquidity shock, the investor is forced to sell the project in period 1. This feature of the model is similar to the preference-shock assumption made by 
Diamond and Dybvig (1983): An investor who is subject to a liquidity shock derives her utility only from period 1 consumption. If, however, she is not subject to a liquidity shock, she derives her utility from period 2 consumption. We denote by $\lambda$ the probability of a liquidity shock. We assume that there are two types of foreign investors. In particular, half of the investors will need to sell with probability $\lambda_{\mathrm{H}}$ and half with probability $\lambda_{\mathrm{L}}$ such that $1>\lambda_{\mathrm{H}}>(1 / 2)>\lambda_{\mathrm{L}}>0$, and $\lambda_{\mathrm{H}}+$ $\lambda_{\mathrm{L}}=1$.

Investors know ex ante whether they are of a $\lambda_{\mathrm{H}}$ type or a $\lambda_{\mathrm{L}}$ type, and this is their private information. In addition to liquidity-based sales, there is a possibility that an investor will liquidate a project in period 1 if she observes a low realization of $\varepsilon$. Then the price that buyers are willing to pay for a direct investment that is being sold in period 1 is

$. P_{D}=\frac{1}{2 A} \frac{\left(1-\lambda_{D}\right) \int_{-1}^{\varepsilon_{D}}(1+\varepsilon)^{2} f(\varepsilon) d \varepsilon+\lambda_{D}}{\left(1-\lambda_{D}\right) \Phi\left(\underline{\varepsilon}_{D}\right)+\lambda_{D}}$

Here, $\underline{\varepsilon}_{\mathrm{D}}$ is a threshold level of $\varepsilon$, set by the direct investor; below which the direct investor is selling the project without being forced to do so by a liquidity shock; $\lambda_{\mathrm{D}}$ is the probability, as perceived by the market, that an FDI investor gets a liquidity shock. In equation (4), it is assumed that if the project is sold because of a liquidity shock, that is, before the initial owner observes $\varepsilon$, the value of $\varepsilon$ is not recorded in the firms before the sale. Therefore, the buyer does not know the value of $\varepsilon$. However, if the project is sold for low-profitability reasons, the owner will know the value of $\varepsilon$ after the sale. The threshold $\underline{\varepsilon}_{\mathrm{D}}$ is determined in equilibrium. The initial owner sets the threshold level $\underline{\varepsilon}_{D}$, such that given the price $P_{\mathrm{D}}$, when observing $\underline{\varepsilon}_{\mathrm{D}}$, 
an investor is indifferent between selling and not selling the project in absence of a liquidity shock. Thus,

$$
P_{\mathrm{D}}=\frac{\left(1+\underline{\varepsilon}_{\mathrm{D}}\right)^{2}}{2 A} \text {. }
$$

Equations (4) and (5) together determine $P_{\mathrm{D}}$ and $\underline{\varepsilon}_{\mathrm{D}}$ as functions of the market-perceived probability of sale due to the liquidity shock $\left(\lambda_{\mathrm{D}}\right)$. We denote these functions as $\underline{\varepsilon}_{\mathrm{D}}\left(\lambda_{\mathrm{D}}\right)$ and $P_{\mathrm{D}}$ $(\lambda \mathrm{D})$.

When a portfolio investor sells the projects in period 1, everybody knows she does it because of a liquidity shock. Thus, the price of the project is given by

$$
P_{\mathrm{p}}=\frac{1}{2 A}
$$

Comparing the price of FDI, which is determined by equations (6A.4) and (6A.5), with the price of FPI, which is determined by equation (6A.6), we see that the resale price of a direct investment in period 1 is always lower than the resale price of a portfolio investment in that period. The intuition is that if a direct investor prematurely sells the investment project, the market price must reflect the possibility that the sale originates from inside information on low prospects of this investment project. This constitutes the second (liquidity) cost of FDI.

Based on our analysis, we can write the ex ante expected net cash flow from FDI:

$$
E V_{\mathrm{D}}\left(\lambda_{\mathrm{i}}, \lambda_{\mathrm{D}}, A, C\right)=\left\{\left(1-\lambda_{\mathrm{i}}\right)\left(\begin{array}{c}
{\left[1+\underline{\varepsilon}_{\mathrm{D}}\left(\lambda_{\mathrm{D}}\right)\right]^{2} \Phi\left[\underline{\varepsilon}_{\mathrm{D}}\left(\lambda_{\mathrm{D}}\right)\right]} \\
+\int_{\underline{\varepsilon}_{\mathrm{D}}\left(\lambda_{\mathrm{D}}\right)}^{1} \frac{(1+\varepsilon)^{2}}{2 A} f(\varepsilon) d \varepsilon
\end{array}\right)+\lambda_{\mathrm{i}} \frac{\left[1+\underline{\varepsilon}_{\mathrm{D}}\left(\lambda_{\mathrm{D}}\right)\right]^{2}}{2 A}\right\}-C
$$


The ex ante expected net cash flow from FPI is simply

$$
E V_{\mathrm{p}}(A)=\frac{1}{2} A
$$

Then, the difference between the expected value of FDI and the expected value of FPI is

$$
\operatorname{Diff}\left(\lambda_{\mathrm{i}}, \lambda_{\mathrm{D}}, A, C\right) \equiv E V_{\mathrm{D}}\left(\lambda_{\mathrm{i}}, \lambda_{\mathrm{D}}, A, C\right)-E V_{\mathrm{p}}(A)
$$

Clearly, investors will choose FDI (FPI) when $\operatorname{Diff}\left(\lambda_{1}, \lambda_{\mathrm{D}}, A, C\right)>0(<0)$ and will be indifferent between the two (i.e., may choose either FDI or FPI) when $\operatorname{Diff}\left(\lambda_{i}, \lambda_{\mathrm{D}}, A, C\right)=0$.

To complete the description of the equilibrium, it remains to be specified how $\lambda_{\mathrm{D}}$, the market-perceived probability that an FDI investor will get a liquidity shock, is determined. Assuming that rational expectations hold in equilibrium, $\lambda \mathrm{D}$ has to be consistent with the equilibrium choice of the two types of investors between FDI and FPI, such that

$\lambda_{\mathrm{D}}=\left(\lambda_{\mathrm{H}} \lambda_{\mathrm{H}, \mathrm{FDI}}+\lambda_{\mathrm{L}} \lambda_{\mathrm{L}, \mathrm{FDI}}\right) /\left(\lambda_{\mathrm{H}, \mathrm{FDI}}+\lambda_{\mathrm{L}, \mathrm{FDI}}\right)$

where $\lambda_{\mathrm{H}, \mathrm{FDI}}$ is the proportion of $\lambda_{\mathrm{H}}$ investors (H investors) who choose FDI in equilibrium, and $\lambda_{\mathrm{L}, \mathrm{FDI}}$ is the proportion of $\lambda_{\mathrm{L}}$ investors (L investors) who choose FDI in equilibrium.

Five possible cases can potentially be observed in equilibrium. Case 1: All investors choose FDI. Case 2: L investors choose FDI; H investors split between FDI and FPI. Case 3: L investors choose FDI; H investors choose FPI. Case 4: $\lambda$ L investors split between FDI and FPI; H investors choose FPI. Case 5: All investors choose FPI. Equilibrium outcomes depend on production cost $A$ and liquidity preferences $\left(\lambda_{\mathrm{L}}, \lambda_{\mathrm{H}}\right)$. 
As the production cost $A$ increases, we are more likely to observe FPI and less likely to observe FDI in equilibrium. As the difference in liquidity needs of the two types of investors widens, we are more likely to see a separating equilibrium, where different types of investors choose different forms of investment.

\section{References}

Alfaro, Laura, Areendam Chanda, Sebnem Kalemli-Ozcan, and Selin Sayek (2004), "FDI and Economic Growth: The Role of Local Financial Markets", Journal of International Economics, 64(1), 89-112.

Antras, Pol (2004), "Advanced Topics in International Trade: Firms and International Trade", Lecture Notes (Harvard University).

Antras, Pol (2015), Global Production: Firms, Contracts, and Trade Structure, Princeton University Press.

Brainard, S. Lael (1997), "An Empirical Assessment of the Proximity-Concentration Trade-off between Multinational Sales and Trade", American Economic Review, 87(4), 520-544.

Bransfetter, Lee (2006), "Is foreign direct investment a channel of knowledge spillovers? Evidence from Japan's FDI in the United States," Journal of International Economics, Volume 68, Issue 2, Pages 325-344.

Coe, D., Helpman, E., (1995). International R\&D Spillovers. European Economic Review, 39, 859-887.

Coe, David T., Elhanan Helpman, and Alexander W. Hoffmaister (2009) "International R\&D spillovers and institutions," European Economic Review, Volume 53, Issue 7, October 2009, Pages 723-741.

de la Potterie, Bruno van Pottelsberghe, and Frank Lichtenberg (2006) "Does Foreign Direct Investment Transfer Technology Across Borders?," Review of Economics and Statistics, August 2001, Vol. 83, No. 3, Pages 490-497. 
Djankov, Simeon, and Bernard Hoekman (2000), Foreign Investment and Productivity Growth in Czech Enterprises, The World Bank Economic Review, 14 (1), 49-64.

Diamond, W. Douglas, and Philip H. Dybvig (1983). "Bank runs, deposit insurance, and liquidity". Journal of Political Economy. 91 (3): 401-419.

Feenstra, Robert C. (1999), "Facts and Fallacies about Foreign Direct Investment", in Martin Feldstein, ed.: International Capital Flows, (University of Chicago Press, Chicago, III).

Friedmann, Yoav (2016), "The Information Technology Industries: Employees, Wages and Dealing with Shocks," Israel Economic Review Vol. 14, No. 1

Goldstein, Itay, and Assaf Razin (2006), “An information-based trade-off between foreign direct investment and foreign portfolio investment," Journal of International Economics, 70, pp. 271295.

Hale, Galina, Assaf Razin and Hui Tong (2014) "Stock Prices in the Presence of Liquidity Crises: The Effect of Creditor Protection," Economica. Volume 81, Issue 322, April Pages 329347.

Helpman, Elhanan (1999) "R\&D and Productivity: The International Connection," in Assaf Razin and Efraim Sadka (eds.) The Economics of Globalization: Policy Perspective from Public Economics, Cambridge University Press.

Razin, Assaf, and Efraim Sadka (2012). Foreign direct investment: analysis of aggregate flows. Princeton University Press. 